\title{
PENGEMBANGAN LEMBAR KERJA SISWA BERBASIS INKUIRI TERBIMBING UNTUK MENINGKATKAN KEMAMPUAN BERPIKIR KRITIS SISWA PADA MATERI SUHU DAN PERUBAHANNYA
}

\author{
Agnes Sulastri Noa ${ }^{1}$, Sudi Dul Aji ${ }^{2}$, Kurriawan Budi Pranata ${ }^{3}$ \\ Program Studi Pendidikan Fisika, Universitas PGRI Kanjuruhan Malang ${ }^{123}$ \\ Email: agnesnoa12@gmail.com
}

\begin{abstract}
Abstrak. Dalam mengembangkan suatu produk baru yaitu berupa lembar kerja siswa merupakan tujuan dari penelitian ini.Penelitian ini menggnakan modle R \& D, yaitu Foour - D Modeels. Kevalidan LKS yang didasarkan dari ketiga ahli yaitu ahli materi, ahli media dan ahli bahasa, penilain produk LKS bebasis inkuiri terbimbing oleh ahli materi, ahli media dan ahli bahasa menunjukan bahwa kualitas LKS termasuk dalam kriteria "Valid" dengan presentase pencapaiannya sebesar 80\%, 73\% dan 85\%. Hasil kepraktisan LKS didasarkan pda anket, presentase pencapaiannya sebesar $88 \%$, untuk uji coba perorangan presentase pencapaiannya sebesar $81 \%$ dengan rata-rata gabungannya 3.69 , untuk uji coba kelompok kecil presentase pencapainnya sebesar $83 \%$ dengan rata-rata gabungannya 3.41 dan uji coba lapangan dengan presentase pencapaiannya sebesar $87 \%$ dengan rata-rata gabungannya 3.37. Hasil keefektivan LKS berdasarkan tes awal dan tes akhir, untuk tes awal diperoleh skor terendahnya 4.30, skor tertinggi 7.10 dengan rata-rata skor 6.60, untuk tes akhir diperoleh skor terendah 6.60, skor tertinggi 8.50, dengan rata-rata skornya 7.25. Rata-rata skor tes akhir tersebut sudah mencapai 70 sehingga telah mencapai kriteria ketuntasan minimal (KKM).
\end{abstract}

Kata Kunci: Pengembangan, Lembar Kerja Siswa, Inkuiri Terbimbing

\section{PENDAHULUAN}

Dalam Fisika sangat berkaitan erat dengan mencari tahu tentang gejalah-gejalah alam yang terjadi disekitar kita (S, 2018). Sehingga sangat berkaitan erat dengan berpikir kritis dalam memecahkan suatu masalah. Berpikir kritis itu sendiri yaitu kemampuan berpikir dari peserta didik agar peserta didik dapat membdakan dan membandingkan suatu informasi atau lebih dengan tujuannya supaya dapat memperoleh pengetahuan melalui pengujian tersebut terhadap gejalahgejalah alamyang terjadi dengan kebenaran ilmiah.

Adapun masalah dari peserta didik yaitu dalam proses pembelajaran peserta didik hanya menjadi objek penerma saja tetapi gurulah yang menjadi pusat pembelajarannya, sehingga peserta didik menerima pengetahuan hanya sebatas membayangkan (secara abstrak), tanpa mengalami dan melakukanya sendiri (Wahyuni, 2012). Padahal dalam pembelajaran fisika tersebut sangat erat kaitanya dengan konsep dan lingkungan sekitar kita. Hal lain yang menyebabkan sulitnya dalam mengaplikasikan fisika kedalam situasi kehidupan real. Bahan ajar yang masih kurang sesuai dengan model pembelajaran yang digunakan juga menjadi suatu penentu proses pembelajaran yang terjadi di dalam kelas, di dalam kelas penggunaan bahan ajar yang masih berpusat pada guru ini membuat para siswa kurang beraktivitas sehingga dapat mengakbatkan kejenhan, siswa kurang semangat untuk belajar fisika (Maulida, 2015).

Untuk itu diperlukan suatu bahan ajar yang dapat membuat peserta didik dapat berpikir kritis, sehingga denga itu peserta didik juga memiliki kesempatan untuk mengembangkan pengetahuannya dengan berpikir kritis (Rahmi, 2013). Pendekatan atau metode yang tepat sangat diperlukan dalam pembelajaran fisika agar dapat membantu pemahaman peserta didik terhadap materi yang diajarkandan juga diharapkan mampu meningkatkan keterampilan berpikir kritis dan 
yang pada akhirnya dapat meningkatkan hasil belajar peserta didik. Bahan ajar yang tepat dan mendukung dalam pembelajaran fisika salah satunya yaitu LKS, sehingga membuat siswa termotivasi dengan berbaga kegiatan yang di arahkan dalam LKS. Dalam LKS juga dapat menghemat waktu yang digunakan karena pemaparan materinya secara singkat sehigga bisa dengan mudah dan cepat untuk menguasai materi.

Pembelajaran berbasis inkuiri terbimbing adalah pembelajaran yang melibatkan siswa dalam merumuskan pertanyaan dalam upayah membangun pengetahuan yang baru (Oktavia, 2019). Disini guru hanya dapat memecahkan masalh yang diberikan untuk siswa yang memberikan pertanyaan-pertanyaan dalam proses penemuan sehingga siswa tidak kebingungan maka siswa lebih memahami materi pembelajaran dan mendapatkan pengalaman belajar secara langsung kepada siswa, disini guru dapat melihat siswa berorientasi, merumuskan masalah, mengajukan hipotesis, mengumpulkan data, menguji hipotesis dan merumuskan kesimpulan, sehingga peserta didik dapat memecahkan masalah-masalah berdasarkan fakta-fakta dan observasi atau pengamatan.

\section{METODE PENELITIAN}

Metode penelitian yang digunakan mengacu pada prosedur pengembangan yang memuat langkah-langkah pokok penelitian pengembangan yang bertujuan untuk menghasilkan produk berupa LKS yang diharapkan dapat digunakan sebgai media pembelajaran bagi siswa untuk memahami materi pelajaran dengan menerapkan model pembelajaran inkuiri terbimbing (Permana, Ardy, 2013).

Model peneltian yaitu penlitian pengembngan $(R \& D)$ yang dikenal degan moodel 4-D ( Four-D Models), yatu tahap penetapan (Define), tahap perancangan (Design), tahap pengembangan (Develop) dan tahap penyebaran (Disseminate).

1) Tahap Penetapan (Define)

Pada tahap ini bertujuan untuk menetapkan apa saja yang dibutuhkan dalam suatu pembelajaran. Dalam tahap ini mengandung analisis dan tujuan pembelajaran yang mencakup analisis ujung depan, analisis peserta didik, analisis tugas, anlisis tugas, spesifikasi tujuan pembelajaran.

2) Tahap Perancangan (Design)

Setelah melakukan tahap penetapan kemudian melkukan pengkjian matri, pengkjian kontn pda LKS haslnya digunkan sebgai acun dalm pengembngan LKS Berbsis Inkiri Terbibing. Pda tahp ini terdpat penyusnan stndar tes, pemilhan media, perncangan prduk.

3) Tahap Pengembangan (Develop)

Pada tahap ini bertujuan untuk menghasilkan perangkat pembelajaran yang dikembangkan pada tahap perancangan sehingga dapat digunakan dalam uji coba. Dalam tahap ini juga merupakan kegiatan penyusunn bahan ajar berupa LKS, penliti meralisasikan hsil perencnaan pda tahp desgn, racangan prduk yang sudah di konsep kemudan dikembngkan melalu langkh-langkh yatu pembatan LKS, validsi produk, melkukan revisi dari hasil valdasi prduk oleh para ahli.

4) Tahap Penyebran (Disseminete)

Pada tahap ini bertujuan untuk penggunaan perangkat yang telah dikembangkan pada skala yang lebih luas, kemudia diimplemntasikan pda sasran yang sesunguhnya, pada saat implemntasi dilakkan pengukurn ketercapian tujun untuk mengetahui efektifitas prodk yang dikembangkan, setelah produk diimplemetasi perlu melihat hasil pencapian tujuan sehigga tujuan yang belum tercapai perlu dijelskan solusinya agar tidak terulang kesalahan yang sama setelah produk disebarluskan.

Dalam prosedur penelitian ini disebutkan juga sifat-sifat komponen pada setiap tahap dalam pengembangan. Langkah-langkah penelitian pengembangan antara lain :

1. Analisis Kebutuhan (Needs Assesment)

Pada tahap ini dapat mengetahui tujuan, mengidentifikasi ketidaksesuaian antara kenyataan dan kondisi yang diinginkan. Biasannya meliputi kajian pustaka, observasi dan persiapan 
laporan awal, ini sangat di gunakan untuk memperoleh informasi awal untuk melakukan pengembangan dan biasannya dilakukan melalui pengamatan kelas.

2. Perencanaan

Dalam tahap ini meliputi tujuan tertentu agar dapat menetapkan suatu prosedur atau langkah.

3. Pembuatan Produk

yaitu meliputi penyiapan bahan-bahan pembelajaran dan alat-alat evaluasi.

4. Validasi Produk Awal

Pada tahap dilkukan respnden perancngan prduk agar dapat merview, memeberikan saran.

5. Revisi Produk Tahap Awal

Dilakukan berdasarkan validasi produk awal, sehingga dapat memperoleh informasi kualitatif tentang produk yang akan dikembangkan.

6. Uji Coba Produk

Dilakukan degan melibatkan bebrapa siswa utuk diuji dalam tes hasil belajar kemudian datannya diolah.

7. Uji Coba Lapangan

Dilkukan dengan melibatkan beberapa siswa untuk diambil datanya dan kemudian diolah.

8. Revisi Produk Tahap Terakhir

Revisian pada tahap akhir ini didasarkan atas masukan dan saran siswa.

9. Penyebaran

Mengembangkan dan memperluas produk di sekolah-sekolah.

Adapun tujuan dari dilakukanya desain pada tahap uji coba yaitu dapat mengetahui perkembangan dari produk yang kita kembangkan agar tercapai tujuannya (Angelina, 2016), yaitu :

1) Tahap Validasi

Yaitu dilakukan oleh beberapa ahli dengan tujuan agar dapat mengetahui produk yang kita kembangkan tersebut dapat kita gunakan dlam kegitan pembeljaran sehingga termotivasi untuk belajar, minat bacanya menigkat, materinya dapat dipahami.

2) Tes Individu

Yaitu tahap yang diberikan untuk mengetahui kekurangan dari produk.

3) Uji Coba Kelompok Kecl

yaitu terdiri dari sepuluh siswa SMP dan masukan dari siswa tersebut yang akan dijadikan revisian untuk peneliti.

4) Uji Coba Skala Luas (Lapangan)

Dalam tahap ini yaitu terdiri dari duapuluh siswa SMP kelas VII dan masukan dari siswa tersebut juga yang akan dijadikan revisian untuk peneliti sehingga dapat menegetahui kelayakan produk akhir.

Dalam penelitian ini cara mengambil data yang digunakan yaitu kuisioner yang berisi suatu pernyataan yang harus dijawab yaitu kuisioner untuk ketiga ahli.

1. Kuisioner Validasi Para Ahli

Dalam validasi ini yang tujuannya untuk melihat dan menilai kekurangan produk dari segi isi dan pembelajaran, segi tampilan dan penyajian, dan aspek keterbacaan.

2. Kuisioner Uji Coba

Digunakan oleh siswa untuk menilai aspek isi dan aspek pembelajaran.

Dalam teknik analisis data dilakukan untuk membuktikan kevalidan pada LKS, kepraktisan dan keefektifan pada LKS yang dikembangkan yaitu :

1. Anaisis Kevalidan LKS

Kriteria validasi menunjukan tingkat kesesuaian antara teori pada LKS yang disusun, apakah bahan ajar yang divalidasi cukup valid atau tidak. Validator dapat menggunakan kriteria dengan menggunakan konversi skor dengan menggunakan skala likert (empat tingkatan). 
Presentase Pencapaian : $P=\frac{\sum x}{N} \times 100 \%$

2. Analsis Keprktisan

Analsis keprktisan didasrkan pda angkt rspon guru dan angkt rspon sswa.

$$
\mathrm{p}=\frac{\text { Banyaknya total skor penilaian }}{\text { Banyaknya skor aspek yang diamati }} \times 100 \%
$$

3. Analsis Kefektifan LKS

Analsis kefektifan LKS berdasarkan tes awal dan tes akhir.

$$
\mathrm{p}=\frac{\text { Banyaknya siswa yang tuntas }}{\text { Jumlah siswa }} \times 100 \%
$$

\section{HASIL DAN PEMBAHASAN}

Penelitian betujuan meghasilkan prduk yang dikembangkan yaitu berupa lembar kerja siswa berbasis inkuri terbmbing untuk meningkatakan kemampuan berpikir kritis siswa, sebagai pendukung pembelajaran IPA khususnya Fisika kelas VII SMP. Dalam LKS ini berisi kompetensi isi, penjelasan materi beserta gambarannya, langkah-langkah dalam menggunakan LKS. LKS ini diamaksutkan dapat membantu siswa dalam belajar agar mudah mengerti tentang suhu dan perubahannya

Dalam validasi ini yaitu oleh tiga ahli.

\section{Validasi Ahli Materi}

Dilakukan oleh dosen fisika, adapun kritik dan masukanya yaitu : Penulisan rumus gunakan equation, Notasi rumus gunakan italic, Sesuaikan gambar dengan pernyataan dan rumus yang ingin disajikan (berikan keterangan gambaryang jelas).

Tabel.1 Data Validasi oleh Ahli Materi

\begin{tabular}{cc}
\hline Aspek Penilaian & Presentase \\
\hline Pembelajaran & $80 \%$ \\
\hline Isi & $80,55 \%$ \\
\hline
\end{tabular}

Berdasarkan penilaian tersebut untuk aspek pembelajaran nomor indikator atau butir soal ada 5 butir soal dengan total keseluruhan yaitu dengan skor 16, sehingga presentase pencapaian aspek pembelajaran olh ahli materi sebesar $80 \%$. Untuk aspek isi nomor indikator atau butir soal ada 9 butir soal dengan total keseluruhan yaitu dengan skor 29 , sehingga presentase pencapaian $80,55 \%$.

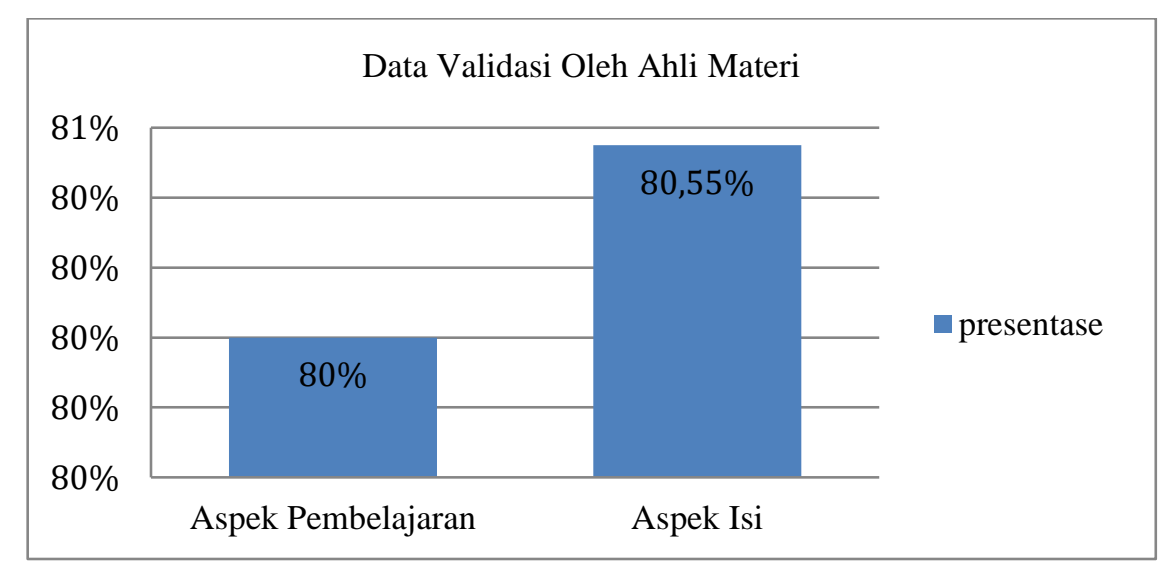

Gambar 1. Data Validasi Oleh Ahli Materi 


\section{Validasi Ahli Media}

Dalam tahap ini dilakukan dosen Fisika di Universitas Kanjuruhan Malang yaitu ibu Chandra Sundaygara S.Pd.,M.Pd, dengan saran dan komentar yang diberikan yaitu : Penggunaan gambar perlu disesuaikan baik ukuran dan tata letak, penggunaan huruf/spasi perlu ditata kembali sehingga terlihat lebih rapih, juga gambar yang digunakan harus disesuai dan dan disertai sumbernya apabila mengambildari ineternet, Cover untuk huruf dan susunan gambarnya dibuat lebih proposional dan huruf lebih terang sehingga tidak terlihat gelap.

Tabel 2. Data Validasi Ahli Media

\begin{tabular}{cc}
\hline Aspek Penilaian & Presentase \\
\hline Tampilan & $73 \%$ \\
\hline Penyajian & $75 \%$ \\
\hline
\end{tabular}

Berdasarkan penilaian tersebut untuk aspek tampilan nomor indikator atau butir soal ada 10 butir soal dengan skor total keseluruhan yaitu 29, sehingga presentase pencapaian sebesar 73\%. Untuk aspek penyajian nomor indikator atau butir soalnya ada 4 butir soal dengan skor total keseluruhannya 12 , sehingga presentase pencapaian sebesar $75 \%$.

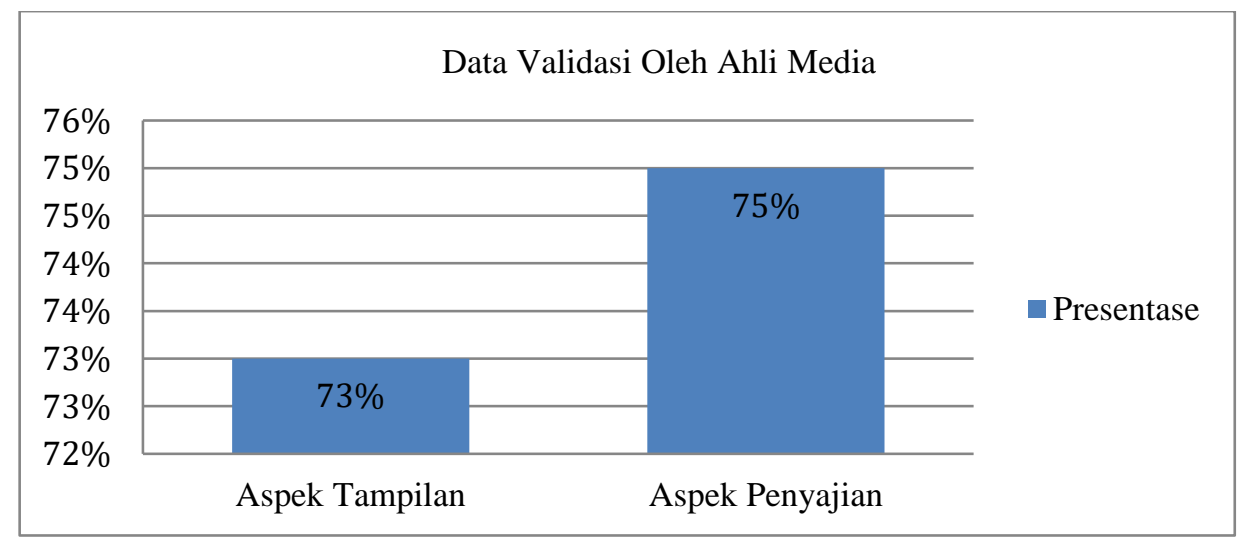

\section{Validasi Ahli Bahasa}

Gambar 2. Data Validasi oleh Ahli Media

Dalam tahap ini divalidasi bapak Dr. Sholikhan, S.Si.,M.Pd, selaku dosen Fisika di Universitas Knjuruhan Malang. Dalam tahap validasi ahli bahasa tidak ada revisi produk yang diberikan dari ahli bahasa.

Tabel 3. Data Validasi oleh Ahli Bahasa

\begin{tabular}{lc}
\hline Aspek Penilaian & Presentase \\
\hline Keterbacaan & $85 \%$ \\
\hline
\end{tabular}

Berdasarkan dari penilaian ahli bahasa yaitu aspek keterbacaan. Untuk aspek keterbacaan nomor indikator atau butir soalnya ada 10 butir soal dengan skor total keseluruhan 34, sehingga presentase pencapaian aspek katerbacaan oleh ahli bahasa sebesar 85\%. Dari penilaian tersebut termasuk dalam kriteria " Sangat Valid " 


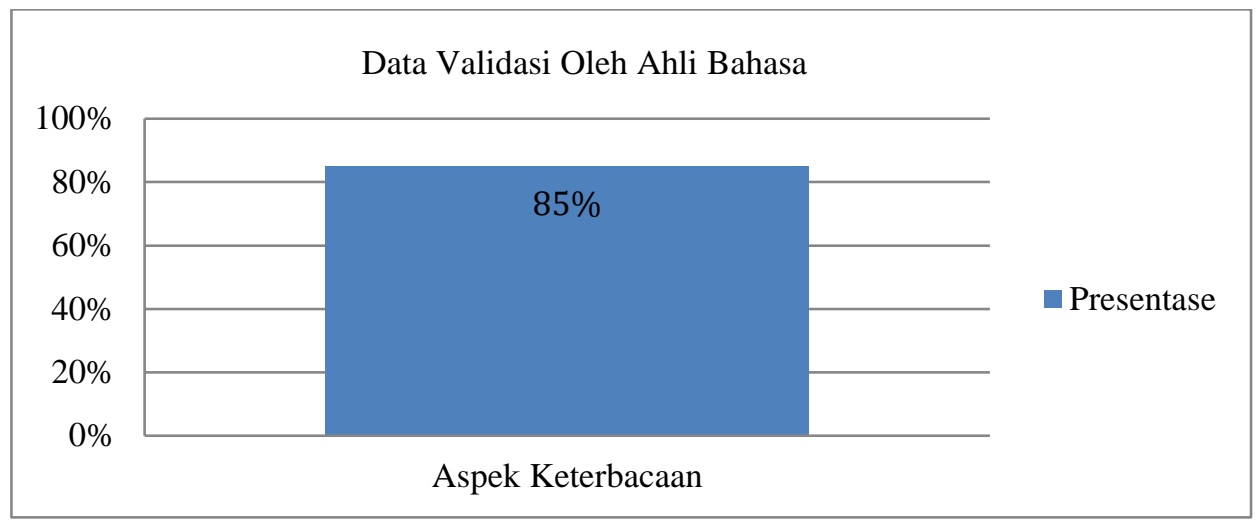

Gambar 3. Data Validasi oleh Ahli Bahasa

Pada penelitian ini bertujuan untuk menghasilkan produk LKS Berbasis Inkuiri Terbimbing dalam mengmbangkan kemapuan berpkir kritis dengan berisi materi suhu dan perubahannya. LKS ini dijadikan pedoman dalam megembangkan keterampilan dan kemampuan siswa, dalam lembar kerja siswa ini dapat menghemat waktu karena dipaparkan secara singkat sehingga dapat pengetahuan, pengalman degan adnya intraksi terhdap lingkunagn.

Pada langkah-langkah pokok penelitian pengembangan yang bertujuan untuk menghasilkan produk berupa LKS yang dapat digunakan sebagai media pembelajaran bagi siswa untuk memahami materi pelajaran dengan menerapkan model pembelajaran inkuiri terbimbing. Pada pembuatan LKS ini mengikuti 4 tahap mdel 4-D (Four-D Models), yaitu penetapan (define), perancangan (design), pengembangan (develop) dan penyebaran (disseminate). Pada tahap penetapan bertujuan untuk menetapkan hal-hal yang diperlukan dalam proses belajar, dalam tahap ini juga mengandung analisis dan tujuan pembelajarannya yang mencakup analisis peserta didik, analisis tugas, analisis konsep dan spesifikasi tujuan pembelajaran, pada tahap perancangan peneliti melakukan pengkajian materi pada LKS lalu hasilnya dignakan sebgai acun dalm pengembngan LKS berbsis inkuri terbmbing, pada tahap pengembangan bertujuan untuk menghasilkan perangkat pembelajaran yang dikembangkan pada tahap sebelumnya sehingga dapat digunakan dalam uji coba, dan pada tahap penyebaran bertujuan menyebarkan produk yang dikembangkan kesekolah-sekolah kemudian diimplementasikan sehingga kita dapat mengetahui keefektifan dari produk tersebut.

Dari hasil penelitian tersebut kevalidan, kepraktisan dan keefektivan LKS berbasis inkuiri ditunjukan melalui data berikut :

1. Kevalidan LKS Berbasis Inkuiri Terbimbing

Kevalidan lembar kerja siswa ini didasarkan pada hasil analisis data ketiga ahli, yaitu sebagai berikut : untuk ahli materi presentase pencapaiannya sebesar $80 \%$. Termasuk dalam kriteria valid, untuk ahli media presentase pencapaiannya sebesar $73 \%$. Dengan kriteria valid, untuk ahli bahasa presentase pencapainnya sebesar $85 \%$, termasuk dalam kriteria valid.

\section{Kepraktisan LKS Berbasis Inkuiri Terbimbing}

Kepraktisan lembar kerja siswa ini didasarkan pada hasil analisis data dri anket, yaitu sebagai berikut : dengan presentase pencapaianya sebesar $88 \%$, untuk individu presentase pencapaiaanya $81 \%$, dengan rata-rata skor gabungan sebesar 3,69, untuk uji coba kelompok kecil presentase pencapaiannya 83\% skor gabungan 3,41, untuk uji coba lapangan dengan presentase pencapiannya $87 \%$ skor gabungan 3,37 .

\section{Keefektivan LKS Berbasis Inkuiri Terbimbing}


Keefektivan lembar kerja siswa ini didasarkan pada pencapaian siswa dalam menyelesaikan tes yaitu sebagai berikut : untuk tes awal (Pre-Test) diperoleh skor terendahnya 4,30, skor tertingginya 7,10 dan rata-rata 6,05. Rata-rata skor tes awal tersebut belum mencapai 70 sehingga belum mencapai kriteria ketuntasan minimal (KKM) yang ditetapakan, untuk tes akhir (Post-Test), diperoleh skor terendah 6,60, skor tertinggi 8,50 dengan rata-rata skor tes akhir tersebut 7,25. Rata-rata skor tes akhir tersebut sudah mencapai 70 sehingga diperoleh simpulan bahwa nilai tes akhir siswa telah mencapai kriteria ketuntasan minimal (KKM).

Adapun karaketristik dari LKS berbasis inkuiri terbimbing ini sebagai berikut :

1. Produk lembar kerja berbasis inkuiri ini sebagai pedoman siswa belajar, merupakan media cetak, memuat tugas beserta gambarannya yanf bervariasi.

Produk LKS berbasis inkuiri terbimbing ini yaitu dijadikan pedoman dlam belajr, berisikan materi dengan dilengkapai gambar yang relavan.

\section{KESIMPULAN}

Berdasarkan pengamatan yang dilakukan dapat disimpulkan yaitu :

1. Kevalidan LKS

Produk LKS memenuhi kriteria kevalidan dengan presentase pencapaian dari ketiga ahli yaitu ahli materi $80 \%$, ahli media $73 \%$ dan ahli bahasa $85 \%$ dengan kategori valid.

2. Kepraktisan LKS

Lembar Kerja Siswa memenuhi kriteria kepraktisan setelah dilakukan uji coba. Presentase pencapaian tahap awal $81 \%$ dengan skor gabungannya 3,69, tahap kedua 83\% dengan skor gabungannya 3,41 dan ujcba lapngan 87\% dengan rta-rta skur gabungannya 3,37 sehingga LKS ini temasuk dalam kategori valid.

3. Keefektifan LKS

Lembar Kerja Siswa memenuhi kriteria keefektifan berdasarkn percoban awal skor 6,05 dan tes akhir skor 7,25 dan telah mencapai kriteria ketuntasan minimal (KKM).

\section{DAFTAR PUSTAKA}

Endang, S. 2018. Pengembangan Lembar Kerja Peserta Didik (LKPD) Berbasis Representasi Ganda Untuk Meningkatkan Minat Dan Hasil Belajar Fisika Peserta Didik SMA. Universitas Negri Yogyakarta.

Ema,Wahyuni.(2012).Pengembangan Lembar Kerja Siswa Matematika SMP Berbasis Kontekstual Untuk Memfasilitasi Pencapaian Kemampuan Memecahkan Masalah.

Maulida, R dan Simanjuntak.M.P: Pengembangan Bahan Ajar Fisika SMA Berbasis Investigasi pada Materi Fluida Dinamis untuk Meningkatkan Hasil Belajar Siswa. Jornal Pendidikan Fisika ISSN 2252-732X, Vol 4. No 1 Juni 2015.

Rahmi, R. (2013).Pengembangan Lembar Kerja Siswa (LKS) Berbasis Inkuiri Terbimbing dan Multimedia Pembelajaran IPA SMP Universitas Lambung Mangkurat, Banjarmasin.

Oktavia, L. (2019). Pengembangan Lembar Kerja (LKS) Berbasis Inkuiri Terbimbing Pada Materi Kalor dan Perubahanyadi Kelas VII SMP Negri 12 Pontianak. Jurnal Pendidikan Sains dan Aplikasinya (JPSA), Vol2 No 1 (2019), Hal 23-27.

Permana, Ardy, Agus Suyatna dan Undang Rosidin. 2013. Pengembangan LKS (Lembar Kerja Siswa) Model Inkuiri Terbimbing Matrei Pokok Optika. Jurnal Pendidikan Fisika, Vol 1 No 5. Hal 55. 